\title{
SPORTOLÁSI SZOKÁSOK VIZSGÁLATA A CAMPUS SPORTFESZTIVÁL TAPASZTALATAI ALAPJÁN
}

\author{
Fenyves Veronika - Dajnoki Krisztina - Bácsné Bába Éva
}

\section{Összefoglalás}

Magyarországon a felsőoktatási hallgatóságot, mint célközösséget megcélzó nyári, nagy tömegeket megmozgató, zenei fesztiválok között található a Debrecenben évente megrendezésre kerülö Campus Fesztivál. A Campus Fesztivál szervezöi kiemelt nagy hangsúlyt fektetnek a zenei események mellett a látogatóközönség sportéletnek fellenditésére is, minden alkalommal megrendezésre kerül a Campus Sportfesztivál, melynek célja a sport és a sportolás népszerüsitése, olyan közösségi esemény megteremtése, ahol a magyarországi, és határon (romániai, szlovákiai és ukrajnai) túli felsöoktatási intézmények hallgatói, szurkolói és versenyzöi kapcsolatot tudnak egymással épiteni. 2017-ben megvalósitott kérdöives felmérés kiértékelésével a felsöoktatási hallgatók sportolási szokásait, sporttal és a sportfesztivállal kapcsolatos motivációit mutatja be a tanulmány, az egyes országokból érkezö hallgatók véleménye közötti különbsége illetve egyezöségre helyezzük a hangsúlyt. Az elemzést SPSS programcsomag segitségével végeztük el, az országok közötti eltéréseket Pearson-féle Chi-négyzet próba, a Kruskal-Wallis test és Cathegorical Principal Component Analysis segitségével vizsgáltuk a sportmotivációs tényezöket.

Kulcsszavak: Sportfesztivál, Felsöoktatási hallgatók, Sportolási szokások, motiváció JEL: Z20 


\title{
ANALYSIS OF THE FINANCIAL SITUATION OF COMPANIES DEALING WITH THE POULTRY AND PIG SECTOR AS A PRIMARY ACTIVITY IN HUNGARY BETWEEN 2005 AND 2015
}

\begin{abstract}
Annual Campus Festival is among summer music festivals in Hungary targeting higher education students that mobilizes large crowds. The organisers of the festival pay special attention to boost the sport life of visitors in addition to music events: Campus Sport Festival also takes place annually to promote sport and to organise a social event where higher education students, fans and participants from Hungary and abroad (Romania, Slovakia and Ukraine) can establish relation with each other. Based on the results of a survey in 2017, a study describes the sport activities and motivation of higher education students in connection with the festival. Differences and similarities among opinions of foreign students take centre stage. The analysis was carried out by SPSS: we used Pearson's Chi-square and Kruskal-Wallis test to find out the differences among countries.
\end{abstract}

Keywords: Sports festival, Higher education students, Sporting habits, motivation JEL: Z20 


\section{Bevezetés}

Magyarországon évente 3-6 ezer fesztivált rendeznek, hiszen a 21. században a kulturális áruk közül ezek a rendezvények tünnek a legpiacképesebbnek. Ezt bizonyítja, hogy éves szinten a fesztiválok 5-6 millió látogatóval büszkélkedhetnek (Benedek-Stark, 2007). A fesztiválok egyik típusát a nyári, nagy tömegeket megmozgató, zenei fesztiválok képezik. Ezek a rendezvények jellegűkből adódóan elsősorban a fiatalabb korosztályok igényeinek kielégítésére törekszenek. Ennek a korosztálynak egyik speciális szegmensét a felsőoktatásban tanulók képezik. A magyarországi könnyüzenei fesztiválok közül mindössze kettő fókuszál célközönségként a felsőoktatási hallgatókra (Bácsné, 2014). Ezek közül az egyik a Debrecenben 2008 óta megrendezésre kerülő Campus Fesztivál, amely látogatói bázisának jelentős részét felsőoktatási intézmények hallgatói adják. A Campus Fesztivál kísérőrendezvényeként megrendezésre kerül Campus Sportfesztivál, melynek föszervezője a Debreceni Egyetem. A Campus Sportfesztivál 2008 óta évente megrendezett sportrendezvény a magyarországi és határon túli felsőoktatási intézmények hallgatói számára. A Campus Sportfesztivál célja a sport és a sportolás népszerüsítése, olyan közösségi esemény megteremtése, ahol a magyarországi, és határon túli felsőoktatási intézmények hallgatói, szurkolói és versenyzői kapcsolatot tudnak egymással építeni. A Sportfesztivál a Campus Fesztivál kapcsolt rendezvénye, mely összeköti a sportot és a szórakozást. A szabadidős trendek (Gödény et. al. 2018) és az aktív és paszszív sportfogyasztási kutatások azt igazolják, hogy a szórakoztató jelleg a sportfogyasztás motivációjában dominánsan megjelenik (Müller et. al. 2011, Koroknay et. al. 2018, Lenténé et. al. 2018, Lenténé et. al., 2019).

Az első két évben magyarországi felsőoktatási hallgatók részvételével, majd 2010ben egy HURO (Magyarország-Románia Határon Átnyúló Együttműködési Program) pályázat segítségével 500 határon túli felsőoktatási hallgató vehetett részt a sporteseményen. A 2010. évi rendezvény óta minden évben van határon túli résztvevője az eseménynek. Az évek alatt Romániából, Ukrajnából és Szlovákiából is vannak/ voltak résztvevőink. A rendezvény kedvelt magyarországi felsőoktatási intézmények körében is. Évente közel húsz magyarországi és közel tíz határon túli felsőoktatási intézményből nagyságrendileg 1000 felsőoktatási hallgató vesz részt a Campus Sportfesztiválon. A rendezvény szervezői a 2017-ben elérkezettnek látták az időt, hogy készítsenek egy szükségletfelmérő kérdőívet, amelyben felmérik a felsőoktatási hallgatók véleményét és igényét a sportfesztiválokról, a szabadidősportokról. Jelen tanulmány a mintában részt vevő felsőoktatási hallgatók sportolási szokásaival összefüggő kérdéseket dolgozza fel, középpontban az egyes országokból érkező hallgatók véleménye közötti különbségre illetve egyezőségre helyezzük a hangsúlyt. Az egyes vizsgálati tényezők (sportfesztivál kezdeményezés értékelése, a sportfesztivál jelentőségének okai, a sportolási tevékenység hanyagolásának az oka) esetében az országok közötti szignifikáns eltéréseket vizsgáljuk. 
Számos kutatás bizonyította a sport pozitív hatását az egyén fizikai, lelki és mentális állapotára (Simon et. al. 2018, Dobay et. al. 2017, Bíró et. al. 2018 a). A sportoló fiatalok közül kevesebben dohányoznak, egészségesebben táplálkoznak, magabiztosabbak, kevesebb pszichoszomatikus tünetük van, viszont a csökkent fizikai aktivitás kapcsolatba hozható a drogfogyasztással, a nem biztonságos szexuális viselkedéssel (Mikulán - Keresztes - Pikó (2010). A rendszeres fizikai aktivitás meghatározó tényezője az egészségmagatartásnak (Nagy -Tobak, 2015, Kovács-Müller 2019; Bíró et. al. 2018 b). Kirk (2005) véleménye szerint a felsőoktatási intézmények adják az utolsó lehetőséget a még oktatásban résztvevő fiataloknak arra, hogy szervezett körülmények között tudjanak sportolni, s beépüljön értékrendjükbe a sportolás az életen át tartó fizikai aktivitás részeként.

\section{Anyag és módszer}

A vizsgálatunkat egy kérdőíves felmérésre építettük, a mintát alapvetően azon felsőoktatási hallgatók alkották, akik részt vettek már egy vagy több alkalommal a minden évben megrendezésre kerülő Campus Sportfesztiválon, és email elérhetőségük szerepelt az adatbázisunkban, vagy érdeklődtek az Campus Sportfesztivál eseménye iránt a facebook oldalunkon. A kérdőív elérhetőségét tartalmazó link 2017. júliusában és augusztusában került kiküldésre emailen és a facebookon keresztül is. A beérkezett kérdőívek alapján elkészült mintát letisztítottuk, kivettük azokat a kérdőíveket, amelyek nem vagy hiányosan voltak kitöltve, ennek eredményeként összesen 1036 db értékelhető kérdőívünk maradt. A válaszadók 18-26 év közötti felsőoktatási hallgatók voltak, 43,3\%-a (449 fö) nő és 56,7\% -a (587 fö) férfi. Négy ország felsőoktatási intézményeinek hallgatói töltötték ki a kérdőívet, 73\%uk (755 fó) magyarországi, 15\%-uk (156fó) romániai, 9\%-uk (94 fó) ukrajnai és 3\%-uk (31 fó) szlovákiai felsőoktatási intézmény hallgatója. A Campus Sportfesztivál célközönsége a magyarországi és a határon túli felsőoktatási hallgatók. Romániából már nyolc éve, Ukrajnából hét éve és Szlovákiából 3 éve érkeznek résztvevők a sporteseményre. Több esetben volt már példa arra is, hogy korábbi résztvevők, akik már a diploma megszerzését követően nem vehettek részt a rendezvényen, ellátogattak és látogatóként, korábbi intézményének szurkolójaként a rendezvényre érkeztek. 
A kérdőívet kitöltők 72\%-a vett már részt valamelyik korábbi rendezvényünkön, a kitöltők 28\%-a személyesen még nem vett részt a sportfesztiválon. Ennek a tényezőnek azért van jelentősége, hogy lesz-e különbség azon felsőoktatási hallgatók sportolási szokása, sporthoz való hozzáállása tekintetében, akik járnak ilyen rendezvényekre, illetve akik nem. Kapunk-e olyan információt a felmérés eredményeként, amelyet felhasználva a későbbiekben a korábban sportfesztivál jellegü rendezvényekre nem járó fiatalokat is a rendezvény résztvevőiként üdvözölhetünk.

Az elemzési minta leíró statisztikai módszereket alkalmaztunk, megoszlási viszonyszámok segítségével mutattuk be a nemek országok és a sportfesztiválon való részvétel alapján a minta szerkezetét. Ezt követően az elemzés során ország (felsőoktatási intézmény helye -Magyarország, Románia, Ukrajna, Szlovákia), mint csoportosító ismérv szerint vizsgáltuk a kérdéseket. Az ország és a sportfesztiválon történő részvétel vizsgálatára a Pearson-féle Chi-négyzet próbát alkalmaztunk. Arra kerestük a választ, hogy az ország szerint eltér-e azok aránya, akik részt vettek vagy nem vettek még részt a sportrendezvényünkön. Elvégzésének nem előfeltétele a mért változók normális eloszlása. A többszörös válaszlehetőséget előíró kérdések elemzése során a megfigyelt értékek a kérdésre adott válaszok elemszámai, az elvárt értékek pedig a sokaságra jellemző megoszlásokkal korrigált számok (Balogh, 2016).

A továbbiakban a kérdőív egyes kérdéseinek az országok szerinti különbségek feltárására nem paraméteres próbát, a Kruskal-Wallis próbát alkalmaztunk. A vizsgált kérdésekre a válaszadóknak egy pontszámmal kellett válaszolni 1-7 között, egy kérdés esetén a "Milyen gyakran sportol?" kérdésre pedig 1-6 között. A KruskalWallis próba az eljárás 3 vagy több minta elemzésére alkalmas módszer. A vizsgálat feltételei: a mintavétel véletlen volta, a minták függetlensége és legalább ordinális változók megléte. Rangtranszformációs eljárásnak is nevezik, mivel a minták egyesítését követően a rangszámok meghatározását kell elvégezni, majd azokat az eredeti csoportok alapján csoportosítani. A transzformált értékek átlagrangjából vonható le a hipotézisre vonatkozó következtetés (Tóthné, 2011).

\section{Eredmények}

A kérdőívet kitöltők sportfesztiválon való részvételét országonkénti bontásban is vizsgáltuk (1. ábra). Elmondhatjuk, hogy a magyarországi válaszadók 33,5\%-a nem vett még részt korábban ezen az eseményen, ez az aránya Románia (11,5\%), Szlovákia (17\%) és Ukrajna (16,1\%) esetében jóval alacsonyabb. 


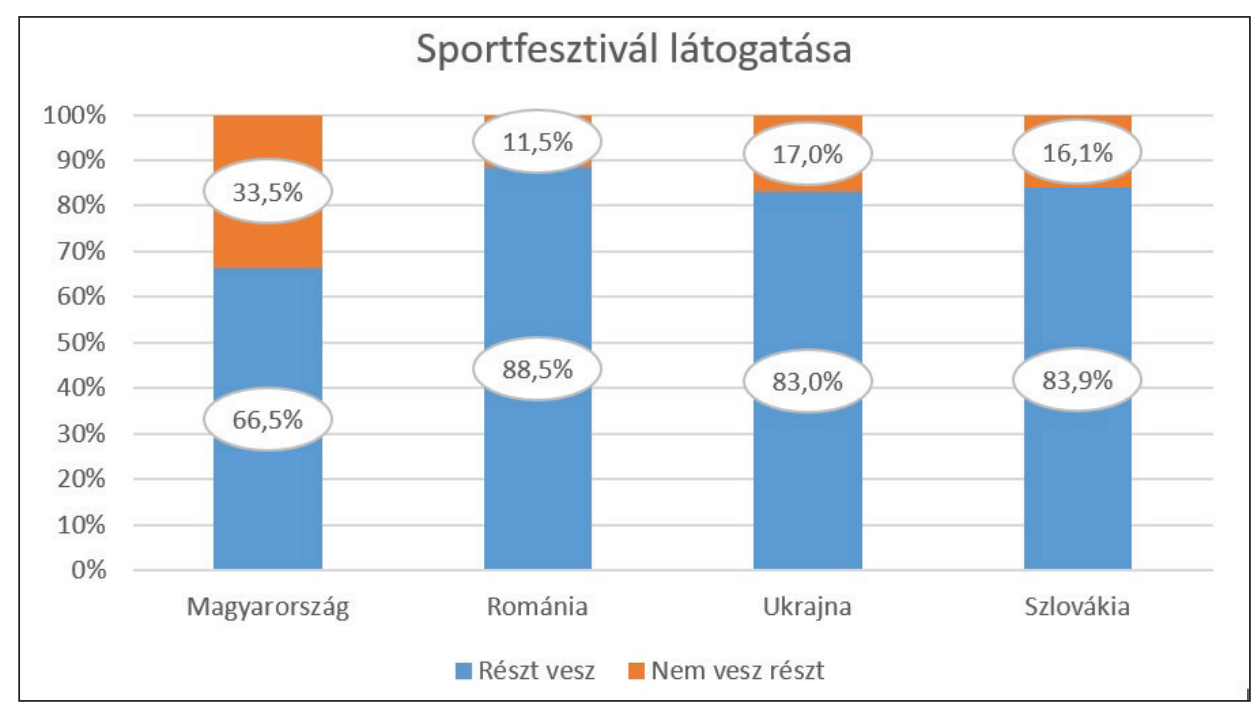

1. ábra: A sportfesztiválon való részvételi arány országonkénti megbontásban Forrás: Saját számitás az adatbázis alapján

A Chi2 próba alapján a sportfesztiválok látogatottságában eltérés adódott országok alapján (Chi2(df:3)=39.9;p<0.001), azonban ez csupán annak köszönhető, hogy Magyarországon szignifikánsan alacsonyabb a látogatottság (67\%) a másik három országhoz képest (83-84-89\%), ahol mint ahogy az 1. táblázat is mutatja 80\% felett van azon kitöltök aránya, akik korábban vettek már részt Debrecenben sportfesztiválon. Arra a kérdésre, hogy hogyan értékeli a sportfesztivál kezdeményezést 749 fó válaszolt, egy hét fokozatú skálán kellett értékelniük (1- egyáltalán nem tartom jó kezdeményezésnek, 7 -nagyon jó kezdeményezésnek tartom) a sportfesztivál kezdeményezést. Országok tekintetében legmagasabb átlagértéket az Ukrajnai (6,51) és a Romániai $(6,42)$ felsőoktatási intézmények hallgatói adták. A legalacsonyabb értékeket a magyarországi intézmények hallgatói adták, 6,65-ös átlagérték jellemezte válaszukat, ami alapvetően egy pozitív eredménynek számít (1. táblázat).

\begin{tabular}{|l|c|c|c|c|c|c|}
\hline \multicolumn{1}{|c|}{ Ország } & \multicolumn{1}{c}{ Átlag } & N & \multicolumn{1}{c}{ Std. Deviation } & Grouped Median & \multicolumn{1}{c|}{ Median } & Skewness \\
\hline Magyarország & 5,65 & 525 & 1,691 & 6,13 & 6,00 & $-1,350$ \\
\hline Románia & $\mathbf{6 , 4 2}$ & 122 & 1,198 & 6,67 & 7,00 & $-2,588$ \\
\hline Ukrajna & 6,51 & 86 &, 793 & 6,62 & 7,00 & $-1,487$ \\
\hline Szlovákia & 5,94 & 16 &, 772 & 5,92 & 6,00 &, 113 \\
\hline Total & 5,88 & 749 & 1,565 & 6,31 & 7,00 & $-1,615$ \\
\hline
\end{tabular}

1. táblázat: A sportfesztivál kezdeményezés értékelése országonkénti bontásban

Forrás: Saját számitás az adatbázis alapján 
A következőkben az összehasonlításokhoz a Kruskal-Wallis féle rangösszeg próbát használtuk a különbségek feltárására. Megvizsgáltuk a sportfesztivál kezdeményezés értékelése és annak a tekintetében, hogy milyen gyakran sportolnak a hallgatók (2. táblázat).

\begin{tabular}{|l|r|r|r|r|}
\hline \multirow{2}{*}{ Megnevezés } & \multicolumn{2}{|c|}{ A sportfesztivál kedveltsége } & \multicolumn{2}{c|}{ A sportolás gyakorisága } \\
\cline { 2 - 5 } & $\mathrm{N}$ & Mean Rank & N & \multicolumn{1}{c|}{ Mean Rank } \\
\hline Magyarország & 525 & 345,62 & 752 & 517,79 \\
\hline Románia & 122 & 454,68 & 156 & 525,50 \\
\hline Ukrajna & 86 & 451,27 & 94 & 490,09 \\
\hline Szlovákia & 16 & 321,56 & 31 & 536,71 \\
\hline Összesen & 749 & & 1033 & \\
\hline
\end{tabular}

2. táblázat: A Kruskal Wallis féle rangösszeg próba eredménye a sportfesztivál kezdeményezés értékelése és a sportolás gyakorisága alapján

Forrás: Saját számitás az adatbázis alapján

A próba elvégzését követően szignifikáns eltérés adódott az sportfesztivál kezdeményezés kedveltségében (Chi2(df:3)=44.6;p<0.001) a felmérésben részt vevő országok között. A rendezvény a legkedveltebb az ukrajnai és a romániai felsőoktatási hallgatók körében, míg a kevésbé kedvelt a szlovákiai és magyarországi felsőoktatási hallgatók között (2. táblázat). Ezt az eredményt egyértelműen alátámasztják a Romániából évről évre növekvő jelentkezési adatok is. Az Ukrajnából érkező felsőoktatási hallgatók esetében sajnos nem beszélhetünk növekvő résztvevői létszámról, mert anyagi okok miatt minden évben csak 1-1 csapat képviselteti magát az adott felsőoktatási intézmény színeiben. A hallgatók a felsőoktatási intézmény támogatásával (étkezés, utazás) tudnak eljutni rendezvényünkre, úgy, hogy ezt a támogatást a Debreceni Egyetem is kiegészíti (például szállás biztosítása). Támogatás nélkül az ukrajnai hallgatók nem tudnának eljutni rendezvényünkre. A romániai hallgatók sokszor önerőből finanszírozzák a rendezvényen való megjelenésüket.

Kíváncsiak voltuk arra, hogy mit jelent a felsőoktatási hallgatóknak a sportfesztivál rendezvény. Egy hét fokozatú skálán minősíthették, hogy mennyire jellemző rájuk az adott tényező. Minden tényező mentén szignifikáns eltérés adódott (3. táblázat). Az adatokat értékelve elmondhatjuk, hogy minden ország felsőoktatási hallgatói esetében a sportolási lehetőség kapta a legmagasabb átlagpontszámot. A sportolási lehetőség mellett magas pontszámokkal értékelték a szórakozási és az élményszerzési lehetősséget is. Összességében a legmagasabb pontszámokat a romániai és az ukrajnai hallgatók, a legalacsonyabbakat a magyarországi hallgatók adták. Elmondható, hogy a minden ország esetében a legalacsonyabb átlagértéket a tanulás, az önmegvalósítás és a nyeremények tényezők kapták. 
Fenyves Veronika, Dajnoki Krisztina, Bácsné Bába Éva

\begin{tabular}{|c|c|c|c|c|c|c|}
\hline Tényező & Magyarország & Románia & Ukrajna & Szlovákia & Chi2 & p \\
\hline Közösségi találka & 5,22 & 5,77 & 5,90 & 5,03 & 29,229 &, 000 \\
\hline $\begin{array}{c}\text { Szórakozási } \\
\text { lehetőség }\end{array}$ & 5,80 & 6,28 & 6,22 & 5,61 & 29,610 &, 000 \\
\hline Élményszerzés & 5,81 & $\mathbf{6 , 3 3}$ & $\mathbf{6 , 3 6}$ & 5,68 & 35,361 &, 000 \\
\hline Kikapcsolódás & 5,41 & $\mathbf{6 , 0 4}$ & $\mathbf{6 , 1 8}$ & 5,03 & 50,206 &, 000 \\
\hline Tanulás & $\mathbf{3 , 3 8}$ & $\mathbf{4 , 2 9}$ & $\mathbf{4 , 4 9}$ & $\mathbf{4 , 0 3}$ & $\mathbf{6 5 , 0 5 5}$ &, 000 \\
\hline Önmegvalósítás & $\mathbf{3 , 8 8}$ & $\mathbf{4 , 8 8}$ & $\mathbf{4 , 9 1}$ & $\mathbf{4 , 7 4}$ & $\mathbf{6 7 , 9 4 0}$ &, 000 \\
\hline Nyeremény & $\mathbf{3 , 8 6}$ & $\mathbf{4 , 3 5}$ & $\mathbf{4 , 3 9}$ & $\mathbf{4 , 4 8}$ & $\mathbf{1 7 , 0 4 5}$ &, 001 \\
\hline Sportolás & $\mathbf{6 , 0 5}$ & $\mathbf{6 , 3 8}$ & $\mathbf{6 , 3 9}$ & 5,94 & 13,874 &, 003 \\
\hline
\end{tabular}

3. táblázat: A sportfesztivál jelentőségének okai országok szerinti megbontásban Forrás: Saját számitás az adatbázis alapján

Vizsgáltuk, hogy a hallgatók milyen gyakran sportoltak a kérdőív kitöltését megelőző néhány hónapban, 39\%-uk iskolán belül hetente egyszer-kétszer,35\%-uk iskolán kívül hetente többször sportol. Elmondható, hogy a megkérdezettek 74\%-a rendszeresen sportol (2. ábra).

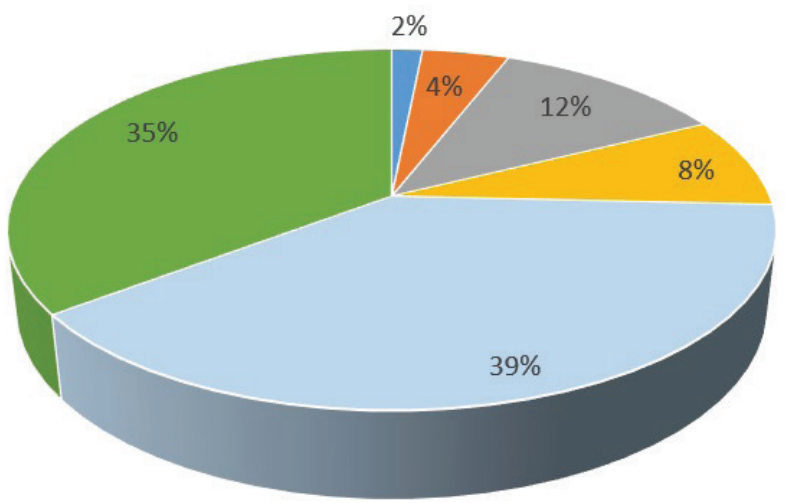

\footnotetext{
- Nem sportoltam egyáltalán, felmentés Nem, az iskolai órákon kívül

- Iskolán kívül alkalmanként - Iskolán kívül havonta egyszer-kétszer

= Iskolán kívül hetente egyszer-kétszer Iskolán kívül hetente többször
}

2. ábra: A felsőoktatási hallgatók sportolási gyakoriságának a megoszlása Forrás: Saját számitás az adatbázis alapján 
A kérdőívet kitöltők 26\%-a nem sportolt rendszeresen ebben az időszakban. Megkérdeztük őket, hogy amennyiben úgy alakul, hogy nem sportolnak rendszeresen ennek milyen okai vannak. Egy hét fokozatú skálán kellett értékelniük az idő hiánya, a motiváció hiánya, a pénz hiánya, az egészségi állapot és a Sportszerek és a hely hiányát. Az idő hiánya, a motiváció hiánya és a Sportszerek és hely hiánya között szignifikáns eltérés adódott, a pénz hiánya és az egészségi állapot megítélése nem különbözött. Az idő hiányát mind a négy ország felsőoktatási hallgatói magas átlagpontszámmal minősítették. Magyarországon emellett a motiváció hiánya, Romániában és Ukrajnában a sportszer és a sportolásra alkalmas helyek hiánya, Szlovákiában pedig az egészségi állapot kapta a második legmagasabb értékelést. Az ukrajnai és a romániai hallgatók elmondása szintén alátámasztja ezt az eredményt, miszerint a felsőoktatási intézmények infrastrukturális felszereltsége fejlesztésre szorul, emellett az ukrajnai hallgatók esetében sokszor a lakóhely közvetlen környezetében sem állnak rendelkezésre a megfelelő sport infrastrukturális feltételek (4. táblázat).

\begin{tabular}{|c|c|c|c|c|c|c|}
\hline Tényező & Magyarország & Románia & Ukrajna & Szlovákia & Chi2 & $\mathrm{p}$ \\
\hline Idő hiánya & 5.01 & 4.57 & 5.05 & 3.84 & 11.116 & .011 \\
\hline $\begin{array}{c}\text { Motiváció } \\
\text { hiánya }\end{array}$ & 3.13 & 2.76 & 2.76 & 2.58 & 9.804 & .020 \\
\hline Pénz hiánya & 2.62 & 2.42 & 2.69 & 2.55 & 2.751 & .432 \\
\hline $\begin{array}{c}\text { Egészségi } \\
\text { állapot }\end{array}$ & 2.41 & 2.73 & 2.72 & 2.71 & 7.240 & .065 \\
\hline $\begin{array}{c}\text { Sportszerek és } \\
\text { hely }\end{array}$ & 2.78 & 2.91 & 3.88 & 2.52 & 25.268 & .000 \\
\hline
\end{tabular}

4. táblázat: A sportolási tevékenység hanyagolásának az oka országok szerinti megoszlásban

Forrás: Saját számitás az adatbázis alapján

Választ kerestünk arra a kérdésre, hogy a sport, mint motivációs tényező milyen helyen helyezkedik el a felsőoktatási hallgatók életében. A Kruskal-Wallis teszt alapján a család, a sport, a pénz és a szerelem motivációs tényezők tekintetében adódott szignifikáns eltérés. Mind a négy ország felsőoktatási hallgatói körében a legmagasabb átlagpontszámot a család és a barátok kapták. Legalacsonyabb értékelést a társadalmi státusz kapta. A sportolást, mint motivációs tényezőt a szlovákiai hallgatók értékelték a legmagasabb átlagpontszámmal, a legalacsonyabb értéket pedig az ukrajnai hallgatóktól kapta. Elmondható, hogy Magyarországon a sport kevésbé fontos motiváció az életben, viszonylag fontos szerepet kapott a pénz, és a legjobban motiváló a többi 
országhoz képest a szerelem, viszont a család relatíve kevesebb szerep kapott. Ukrajnában különösen fontos a család. A román válaszadók relatíve alacsonyabb értékeket adtak minden kategóriában a többieknél (5. táblázat).

\begin{tabular}{|c|c|c|c|c|r|r|}
\hline Tényező & Magyarország & Románia & Ukrajna & Szlovákia & \multicolumn{1}{c|}{ Chi2 } & \multicolumn{1}{c|}{$p$} \\
\hline Család & 6.55 & 6.57 & 6.88 & 6.61 & 13.374 & .004 \\
\hline Sport & 5.05 & 5.40 & 5.63 & 5.81 & 22.310 & .000 \\
\hline Pénz & 5.07 & 4.81 & 4.73 & 5.29 & 14.330 & .002 \\
\hline Szerelem & 5.78 & 5.40 & 5.60 & 5.42 & 10.092 & .018 \\
\hline Barátok & 6.14 & 6.04 & 6.22 & 6.19 & 1.203 & .752 \\
\hline $\begin{array}{c}\text { Társadalmi } \\
\text { Státusz }\end{array}$ & 4.32 & 4.53 & 4.54 & 4.71 & 4.986 & .173 \\
\hline Karrier & 5.55 & 5.61 & 5.44 & 5.74 & 3.521 & .318 \\
\hline Szórakozás & 5.17 & 5.21 & 5.11 & 5.65 & 3.512 & .319 \\
\hline
\end{tabular}

5. táblázat: A különböző motivációs tényezők alakulása a felsőoktatási

hallgatók életében országok szerinti megoszlásban

Forrás: Saját számitás az adatbázis alapján

\section{Következtetések, javaslatok}

A szakirodalom megállapította, hogy a felsőoktatási intézmények adják az utolsó lehetőséget a még oktatásban résztvevő fiataloknak arra, hogy szervezett körülmények között tudjanak sportolni, s beépüljön értékrendjükbe a sportolás az életen át tartó fizikai aktivitás részeként. A felsőoktatási intézmények által szervezett sportprogramok - mint a Magyarországon, Debrecenben minden évben megrendezésre kerülő Campus Sportfesztivál - hozzá tudnak járulni ehhez a folyamathoz. Tanulmány a mintában részt vevő felsőoktatási hallgatók (1036 fö) sportolási szokásaival összefüggő kérdéseket dolgoztunk fel, középpontban az egyes országokból érkező hallgatók véleménye közötti különbségre illetve egyezőségre helyezzük a hangsúlyt. Megállapítottuk, hogy a sportfesztivál kezdeményezés értékelése tekintetében szignifikáns eltérés adódott a sportfesztivál kezdeményezés kedveltségében az felmérésben részt vevő országok között. A sportfesztivál jelentőségének okainak vizsgálata során megállapí- 
tásra került, hogy minden tényező (közösségi találka, szórakozási lehetőség, élményszerzési lehetőség, kikapcsolódás, tanulás, önmegvalósítás, nyeremény és sportolás) mentén szignifikáns eltérés adódott. A sportolási tevékenység hanyagolásának az oka vizsgálata során az idő hiánya, a motiváció hiánya és a sportszerek és hely hiánya között szignifikáns eltérés adódott, a pénz hiánya és az egészségi állapot megítélése nem különbözött az országok között. A sportmotiváció vizsgálata során az országok között a vizsgált motivációs tényezők többsége esetén szignifikáns eltérést tapasztalhattunk.

\section{Köszönetnyilvánítás}

A publikáció elkészítését az EFOP-3.6.2-16-2017-00003 számú projekt támogatta. A pro-jekt az Európai Unió támogatásával, az Európai Szociális Alap társfinanszírozásával valósult meg.

\section{Hivatkozott források}

[1.] Benedek M. - Stark J. (2007) Fesztiválvilág In: Turizmus Bulletin Heiling Média Kiadó Kft. Budapest XIII. évf. 3. szám

[2.] Bácsné B. É. (2014): Ha a hallgató vizsgáztat - elégedettségi vizsgálat a Campus Fesztivál 2013-on ACTA SCIENTIARUM SOCIALIUM 17:(40) Kaposvári Egyetem, Kaposvár pp. 51-60

[3.] Balogh P. (2016): Egy alternatív fehérjeforrás érékelése: a rovarfogyasztás kihívásai és lehetőségei ÉLELMISZER, TÁPLÁLKOZÁS ÉS MARKETING XII:(2) pp. 11-24.

[4.] Biró M. - Pucsok J.M. - Hidvégi P. - Tatár A. - Lenténé P.A. (2018a): Az Északalföldi régió lakosságának egészségi állapota - a mozgás potenciálja.In: Balogh, László (szerk.) Fókuszban az egészség.Debrecen, Magyarország : Debreceni Egyetem Sporttudományi Koordinációs Intézet, (2018) pp. 61-72., 12 p.

[5.] Biró M. - Hidvégi P. - Tatár A. - Pucsok J.M. - Puskás Lenténé A. (2018b): Possibilities for improving the quality of life in Hungary in the northern great plain region. In: Jaromír, Šimonek; Beáta, Dobay (szerk.) Sport science in motion: proceedings from the scientific conference. Športová veda v pohybe: recenzovaný zborník vedeckých a odborných prác z konferencie. Mozgásban a sporttudomány: válogatott tanulmányok a konferenciáról. Komárno, Szlovákia : Univerzita J. Selyeho, (2018) pp. 227-235. , 9 p. 
[6.] Dobay, B. - Müller, A. - Bendíková E. (2017): Adult Health in Terms of Selected Lifestyle Factor. DISPUTATIONES SCIENTIFICAE UNIVERSITATIS CHATHOLICAE IN RUZOMBEROK 17 : 4 pp. 32-39.

[7.] Gődény, N.- Biró, M.- Lenténé, P.A.; Lente, L.; Müller, A. (2018):A fogyasztói szokások és trendek változásának vizsgálata a fitnesz területén. In: Balogh, László (szerk.) Fókuszban az egészség.Debrecen, Magyarország : Debreceni Egyetem Sporttudományi Koordinációs Intézet, (2018) pp. 9-18. , 10 p.

[8.] Kirk, D. (2005): Physical Education, Youth Sport and Lifelong Participation: the Importanceof Early Learning Experiences. European Physical Education Review, 11. 3. sz. 239-255

[9.] Koroknay, Zs. - Müller, A. -Bíró, M. (2018):A 17. FINA Vizes Világbajnokság sport, társadalmi és gazdasági hatásai. In: Balogh, László (szerk.) Fókuszban az egészség.Debrecen, Magyarország : Debreceni Egyetem Sporttudományi Koordinációs Intézet, (2018) pp. 116-129.

[10.] Kovács, K. - Müller, A. (2019): Rizikó-magatartással jellemezhető hallgatók tanulmányi kockázatai . ACTA MEDICINAE ET SOCIOLOGICA $10: 28$ pp. 63-78.

[11.] Lenténé P. A. - Hidvégi P. - Tatár A.- Pucsok J.M - Biró M. (2018):Recreational potential of the northern great plain region in Hungary.In: Jaromír, Šimonek; Beáta, Dobay (szerk.) Sport science in motion : proceedings from the scientific conference. Športová veda v pohybe: recenzovaný zborník vedeckých a odborných prác z konferencie. Mozgásban a sporttudomány: válogatott tanulmányok a konferenciáról.Komárno, Szlovákia : Univerzita J. Selyeho, (2018) pp. 218-226. , 9 p.

[12.] Lenténé, P.A. - Tatár, A. - Lente, L. - Pucsok, J.M. - Bíró, M.- Hidvégi, P. (2019):A sport és wellness elemek megjelenése az Észak- alföldi régió három-, négy- és ötcsillagos szállodáinak kínálatában. In: Bácsné, Bába Éva; Müller, Anetta (szerk.) „Mozgással az egészségért” A fizikai aktivitás jelentosége a jövő munkavállalóinak egészségmegőrzésében : Nemzetközi Konferencia és Workshop: Válogatott tanulmánykötet = „Movement for health” The importance of physical activity in health protection of future workers: International Conference and Workshop: Proceedings from the International Conference and Workshop.Debrecen, Magyarország : Debreceni Egyetem, (2019) pp. 204-215. , 12 p. 
[13.] Mikulán R. - Keresztes N. - Pikó B. (2010): A sport mint védőfaktor: fizikai aktivitás, egészség, káros szenvedélyek. In: Pikó B. (szerk.): Védőfaktorok nyomában. A káros szenvedélyek megelőzése és egészségfejlesztés serdülőkorban. L’Harmattan - Nemzeti Drogmegelőzési Intézet, Budapest. 115-130.

[14.] Müller, A. - Széles-K. Gy. - Seres, J. - Kristonné B. M. (2011): Főiskolai hallgatók rekreációs tevékenységei. REKREACIO.EU 1. : 4. pp. 31-34.

[15.] A Nagy; J Tobak The role of sport infrastructure: use, preferences and needs APSTRACT - APPLIED STUDIES IN AGRIBUSINESS AND COMMERCE 9:(1-2)2015. pp. 47-52.

[16.] Simon, I.Á.- Kajtár, G. - Herpainé, L.J. - Müller, A. (2018):A fizikai aktivitás és a mentális egészség jelentősége a 60 év fölötti korosztály életében. KÉPZÉS ÉS GYAKORLAT: TRAINING AND PRACTICE 16 : 1 pp. 25-36. , 12 p. (2018)

[17.] Tóthné P. L. (2011): A kutatásmódszertan matematikai alapjai Eszterházy Károly Főiskola, Eger p.54.

\section{Szerzők:}

\section{Dr. habil Fenyves Veronika}

Egyetemi docens, Tanszékvezető, oktatási dékánhelyettes

Debreceni Egyetem, Gazdaságtudományi kar

Számviteli és Pénzügyi Intézet

fenyves.veronika@econ.unideb.hu

\section{Dr. habil Dajnoki Krisztina}

Egyetemi docens, intézetigazgató

Debreceni Egyetem, Gazdaságtudományi kar

Vezetés- és Szervezéstudományi Intézet

dajnoki.krisztina@econ.unideb.hu

\section{Dr. Bácsné Bába Éva}

Egyetemi tanár, Tanszékvezető

Debreceni Egyetem, Gazdaságtudományi kar

Vidékfejlesztés, Turizmus- és Sportmenedzsment Intézet

bacsne.baba.eva@econ.unideb.hu 